\title{
From Prison to Lecture Theatre: Open Book Drop-In Sessions at the University of Greenwich
}

\author{
Janice Larkin \\ Access \& Widening Participation Unit \\ Fiona Taylor \\ Open Book Project, Goldsmiths College, University of London
}

"It's not about rehab; it's about becoming the people we always should have been. We're not victims, we're survivors. Victims don't have the power to change things. We have." This is the strongly held belief of Joe Baden, the co-ordinator of the Open Book Project, who inspired the drop-in sessions at the University of Greenwich. Joe also says, "To build self-esteem you must do esteemable things." The drop-in sessions are helping to give people the tools to make those changes and to do esteemable things.

The Open Book drop-in sessions were originally funded by a University of Greenwich Dragons' Den bid, based on the television series of the same name. We had five minutes to pitch an idea to a panel of five people including the Pro Vice-Chancellor, at least two Heads of School and an external industry representative. Applications had to be innovative, bidding for a maximum of $£ 3,000$.

Following the pitch, the panel asked questions and a decision was given immediately. This was a nerve-wracking process but nowhere near as frightening as first setting foot on campus can be for some of our students.

In 'Been There, Done That' (Hoare 2004), an Open Book student explains why peer support is so important. "I'm doing a BA ... but the academic stuff is almost the easy bit. What's tough is making friends, as there are so few people here who have experienced the kind of life I have. And it's not much easier at home, as l've had to drop many of the old friends I used to hang around with." This student from a very dysfunctional family, was suspended from primary school for theft, quickly found support and friendship within a gang and moved on through ASBOs, to a Young Offenders' Institute and finally to prison. Fortunately, on leaving prison he decided the time had come to change his life and do those esteemable things. Breaking with his old life was very difficult and he may not have succeeded without the peer support offered by Open Book.

The University of Greenwich Open Book drop-in sessions offer support to students from nontraditional backgrounds, including ex-addicts, ex-offenders and those with mental health problems. 
The sessions are open access once a week throughout the year and at first ran for two hours but now extend to four. The sessions are staffed by an Open Book study skills tutor and experienced student ambassadors. They offer: a conduit to pre-existing support, a comfortable place to talk, help in interpreting the bureaucracy, study skills and a safe non-judgemental space. The defining ethos is that they are run by staff and students who come from similar backgrounds and are therefore able to offer real peer support. Within the same session someone may be both a tutor and a student; there is no hierarchy.

Peer support, albeit in the area of mental health, is defined by Gartner and Reissman (1982) as "social emotional support .... that is mutually offered or provided by persons having a mental health condition to others sharing a similar mental health condition to bring about a desired social or personal change". If we expand this definition beyond mental health, it is an accurate description of the function and purpose of the sessions. The desired change being successful completion of a higher education programme.

We are also able to show that there are other benefits to those who attend the drop-in sessions.

- Student A almost had to quit because of financial difficulties but is now teaching in an further education college.

- Student B almost gave up several times due to loss of confidence and self-doubt but is still attending, doing very well and has been offered a Master's programme at a leading London institution.

- 35 students have attended, approximately $33 \%$ regularly and none have so far left university.

- Two close to suicide but still here and getting help.

All of these students are more likely to stay at university but the benefits stretch far beyond the campus walls - they will become people who contribute to society rather than taking from it.

We believe that the sessions have been successful because they offer an informal relaxed and safe atmosphere where students can find their own route to finding solutions to problems. The final word is left to a student, "It works because it is halfway between everyday and academic, and so general conversation leads to disclosure."

\section{References}

Gartner, A., and Riessman, F. (1982). Self-help and mental health. Hospital and Community Psychiatry, 33: 631-635.

Hoare, S. (2004). Been there, done that. The Guardian, 29 June. 